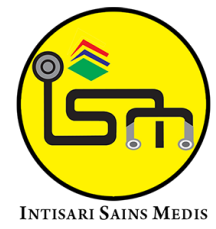

Published by Intisari Sains Medis

\title{
Manajemen multidisiplin Oral Squamous Cell Carcinoma (OSCC): laporan kasus
}

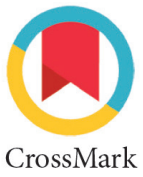

\author{
Ni Putu Riskayanti1", Dahlia Riyanto', Saka Winias²
}

\section{ABSTRACT}

Background: Oral squamous cell carcinoma (OSCC) is the most common type of oral cancer and represents more than $90 \%$ of all head and neck cancers. The etiology of OSCC is multifactorial. The uses of tobacco, heavy alcohol drinking, less consumption of vegetables and fruit, genetics, trauma and viruses are considered possible risk factors of the OSCC. This case study aims to evaluate the multidiscipline management of OSCC at Universitas Airlangga Dental and Oral Hospital, Surabaya, Indonesia.

Case Presentation: This case report presents a 45-year-old female patient who came with chief complaints of ulcer on the lateral right of the tongue that persistent for 3 months ago. The patient also complained of pain when speaking, eating, swallowing, and the pain felt into the right head. The patient has no history of tobacco and alcohol consumption, but her sister has a history of breast cancer. No extraoral abnormalities were found. Intraoral examination results showed a single ulcer with induration on the lateral dextra of the tongue and diffuse pseudomembranous on the dorsal of the tongue. Based on history taking and clinical examination, the patient was suspected of OSCC. The management included debridement of the lesion, complete blood count, fasting blood glucose, HbATC, and anatomical pathology examination. The patient has also been prescribed anesthetics, antiinflammation and antiseptic mouthwash. The patient was then referred to the head and neck oncologist for hemiglossectomy. Two months after the surgery, there is no complaint of the lateral right of the tongue. The patient also has no complaint about eating and swallowing.

Conclusion: The dentist plays an important role in identifying $\mathrm{OSCC}$. The early diagnosis and proper multidisciplinary management of OSCC could improve the prognosis of the case and the patient's life quality.

Keywords: Oral Squamous Cell Carcinoma, Management, Multidisciplinary.

Cite This Article: Riskayanti, N.P., Riyanto, D., Winias, S. 2021. Manajemen multidisiplin Oral Squamous Cell Carcinoma (0SCC): laporan kasus. Intisari Sains Medis 12(2): 621-626. D01: 10.15562/ism.v12i2.1076

\section{ABSTRAK}

${ }^{1}$ Residen Program Pendidikan Dokter Gigi Spesialis (PPDGS) IImu Penyakit Mulut, Fakultas Kedokteran Gigi, Universitas Airlangga, Surabaya, Indonesia; ${ }^{2}$ Departemen IImu Penyakit Mulut, Fakultas Kedokteran Gigi, Universitas Airlangga, Surabaya, Indonesia;

\section{*Korespondensi:}

Ni Putu Riskayanti;

Residen Program Pendidikan Dokter Gigi Spesialis (PPDGS) IImu Penyakit Mulut, Fakultas Kedokteran Gigi, Universitas Airlangga, Surabaya, Indonesia; riskapt18@gmail.com

Diterima: 03-06-2021

Disetujui: 21-08-2021

Diterbitkan: 31-08-2021
Latar belakang: Oral squamous cell carcinoma (OSCC) adalah jenis kanker mulut yang paling umum dan ditemukan hampir pada 90\% dari semua kasus karsinoma di rongga mulut. Etiologi OSCC adalah multifaktorial. Penggunaan tembakau, konsumsi alkohol berlebihan, konsumsi sayur dan buah yang lebih sedikit, genetika, trauma dan virus dianggap sebagai faktor risiko OSCC. Laporan kasus ini bertujuan untuk mengevaluasi manajemen multidisipin OSCC pada Rumah Sakit Gigi dan Mulut (RSGM) Universitas Airlangga, Surabaya, Indonesia.

Presentasi Kasus: laporan kasus ini menyajikan kasus seorang pasien wanita berusia 45 tahun yang datang dengan keluhan utama ulserasi pada lateral lidah kanan yang menetap sejak 3 bulan yang lalu. Pasien juga mengeluh nyeri saat berbicara, makan, menelan dan nyeri terasa di kepala kanan. Pasien tidak memiliki riwayat konsumsi tembakau dan alkohol tetapi saudara perempuannya memiliki riwayat kanker payudara. Tidak ditemukan kelainan ekstraoral. Hasil pemeriksaan intraoral menunjukkan ulser tunggal dengan indurasi pada lateral lidah dekstra dan pseudomembran difus pada dorsal lidah. Berdasarkan anamnesis dan pemeriksaan klinis, diagnosa sementara adalah OSCC. Penatalaksanaan meliputi debridement lesi, hitung darah lengkap, glukosa darah puasa, HbA1c, dan pemeriksaan patologi anatomi. Pasien juga diresepkan obat kumur anestetikum, antiinflamasi dan antiseptik. Pasien kemudian dirujuk ke Departemen Bedah Onkologi Kepala Leher untuk dilakukan hemiglosektomi. Dua bulan setelah operasi, tidak ada keluhan pada lidah pasien. Pasien juga tidak memiliki keluhan saat makan dan menelan. Simpulan: Dokter gigi memiliki peran yang penting 
dalam mengidentifikasi OSCC. Diagnosis dini dan prognosis kasus dan kualitas hidup pasien. manajemen multidisplin tepat dapat meningkatkan

Kata kunci: Oral Squamous Cell Carcinoma, Manajemen, Multidisiplin.

Sitasi Artikel ini: Riskayanti, N.P., Riyanto, D., Winias, S. 2021. Manajemen multidisiplin Oral Squamous Cell Carcinoma (OSCC): laporan kasus. Intisari Sains Medis 12(2): 621-626. D0I: 10.15562/ism.v12i2.1076

\section{PENDAHULUAN}

Oral Squamous Cell Carcinoma (OSCC) adalah jenis kanker mulut yang paling umum dan ditemukan hampir pada $90 \%$ dari semua kasus karsinoma di rongga mulut. ${ }^{1,2}$ Lebih dari 90\% kanker mulut terjadi pada pasien yang berusia di atas 45 tahun dengan predileksi tersering pada laki-laki. Etiologi OSCC adalah multifaktorial. Penggunaan tembakau, konsumsi alkohol berlebihan, konsumsi sayur dan buah yang lebih sedikit, genetika, trauma dan virus dianggap sebagai faktor risiko OSCC. ${ }^{2}$

OSSC biasanya muncul sebagai ulserasi dengan pinggiran eksofitik dan persisten dalam jangka waktu lebih dari 2 minggu. ${ }^{2}$ Terlambatnya deteksi dan diagnosa dari OSCC akan menunda dimulainya perawatan dan hal ini merupakan salah satu faktor utama berkurangnya tingkat kelangsungan hidup pasien., ${ }^{1,2}$

Perawatan OSCC umumnya memerlukan tim dari berbagai multidisplin dimana tujuan utama pengobatan adalah untuk menyembuhkan pasien, mencegah kekambuhan dan sebisa mungkin mengembalikan bentuk dan fungsi dari daerah yang terkena., Operasi dilakukan jika ukuran tumor kecil dan dapat menghasilkan hasil yang memuaskan secara fungsional. ${ }^{1}$

Berdasarkan pada pemaparan di atas, studi kasus ini bertujuan untuk memaparkan tatalaksana multidisiplin OSCC meliputi peran dokter gigi dalam mengidentifikasi kasus OSCC hingga.

\section{LAPORAN KASUS}

Seorang pasien wanita berusia 45 tahun datang ke RSGM Universitas Airlangga Surabaya pada tanggal 4 November 2019 dengan keluhan utama sariawan pada samping kanan lidah sejak 3 bulan lalu dan terasa nyeri. Riwayat perjalanan penyakit yaitu awalnya nampak sebagai
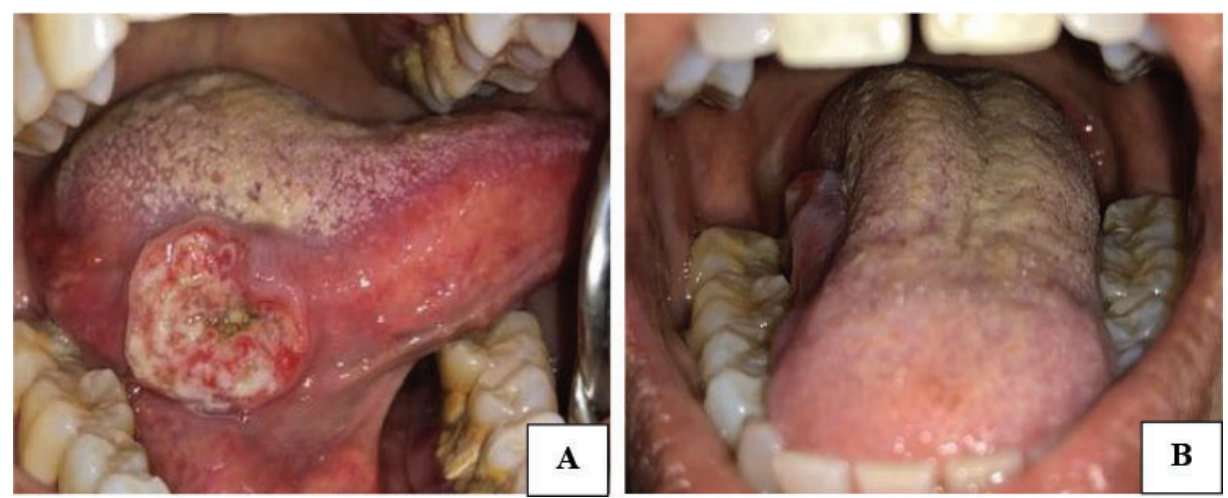

Gambar 1. (A) Ulser soliter berbentuk oval dengan warna putih kekuningan, batas jelas, tepi ireguler, dan terdapat indurasi; (B) dorsal lidah terdapat pseudomembran, berwarna putih, batas difus, dan tepi ireguler.

sariawan kecil, muncul tiba-tiba, berwarna putih disertai nyeri. Untuk mengurangi keluhannya, pasien berkumur dengan obat kumur antiseptik 2 kali sehari, tapi tidak ada perubahan. Kemudian pasien pergi berobat ke puskesmas, diresepkan antibiotik dan antinyeri yang dikonsumsi 3 kali sehari. Secara bersamaan, pasien juga minum teh herbal 1 kali seminggu, menggunakan obat antijamur tetes $2 \mathrm{kali}$ sehari namun tetap tidak ada perubahan. Sejak 1 bulan lalu, pasien merasa sariawannya semakin membesar dan tidak pernah sembuh. Pasien kemudian kembali berobat ke puskesmas dan diresepkan obat yang sama seperti sebelumnya yaitu antibiotik dan antinyeri untuk dikonsumsi 3 kali sehari tapi tidak rutin dikonsumsi oleh pasien dan tidak ada perubahan. Sejak 10 hari lalu, pasien menggunakan obat kumur herbal, namun tetap tidak ada perubahan. Pasien merasa nyeri ketika membuka mulut, berbicara, makan dan menelan. Rasa nyeri juga dirasakan menyebar hingga ke kepala kanan. Untuk mengurangi keluhannya pasien minum obat antinyeri. Obat antinyeri masih sisa sekitar 20-30 biji. Pasien tidak memiliki riwayat sariawan berulang. Terakhir kali mengalami sariawan sekitar 1 atau 2 tahun

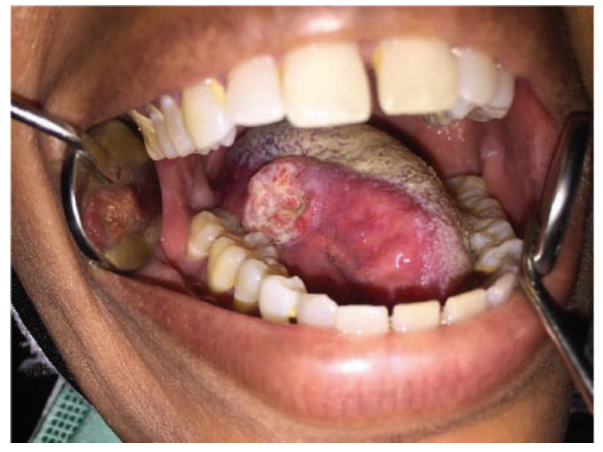

Gambar 2. Ulser soliter berbentuk oval, berwarna putih kekuningan, batas jelas, tepi ireguler, dan terdapat indurasi.

lalu, muncul tiba-tiba dan sembuh dalam waktu 3 hari setelah diobati dengan obat oles berwarna hijau. Pasien menyangkal memiliki penyakit sistemik. Riwayat kesehatan keluarga nenek dari ayah, ibu, paman dan bibi pasien memiliki riwayat diabetes, ayah pasien memiliki riwayat hipertensi dan kakak perempuan pasien memiliki riwayat kanker payudara.

Pemeriksaan klinis ekstra oral tidak ditemukan adanya abnormalitas. Pemeriksaan klinis intra oral pada lidah lateral dextra terdapat ulser, soliter, oval, 

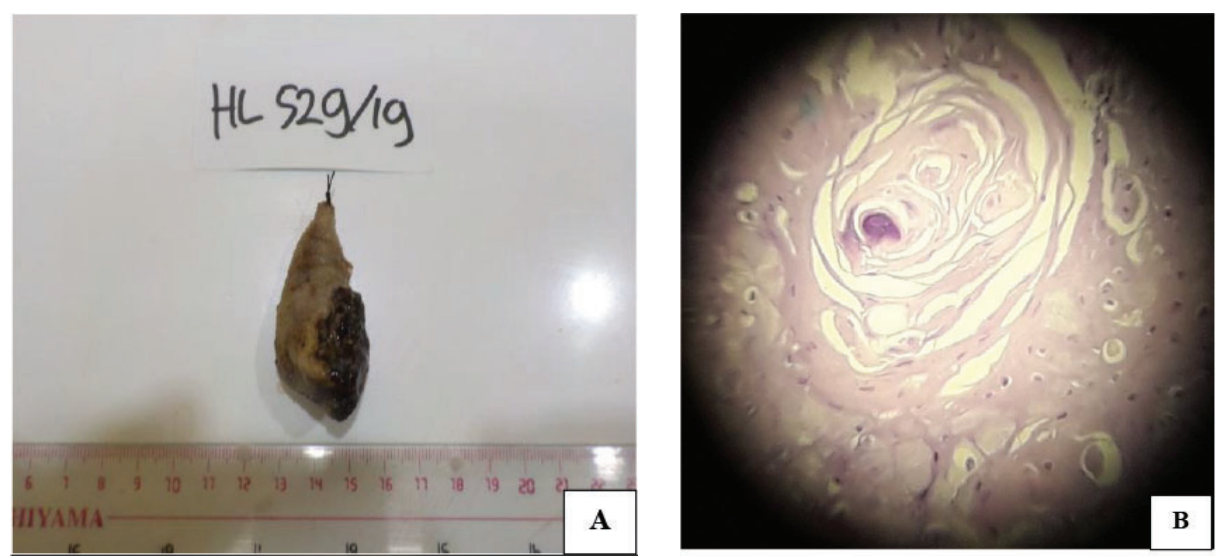

Gambar 3. (A) Hemiglosektomi dan (B) Hasil pemeriksaan histopatologi anatomi.
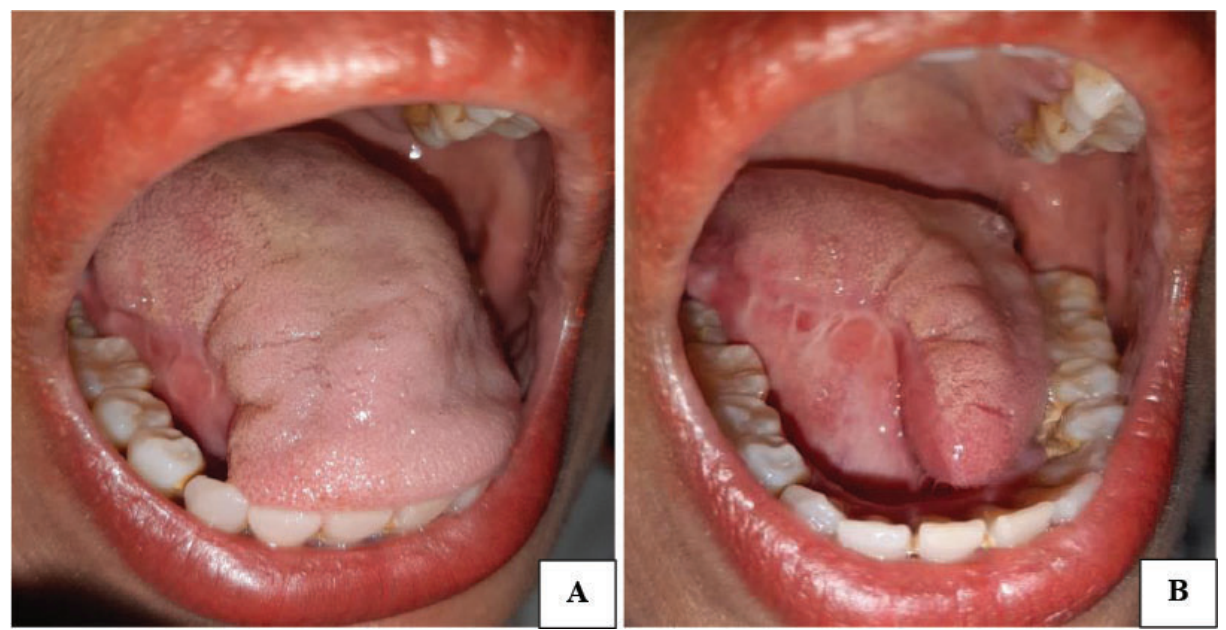

Gambar 4. (A) Post hemiglossectomy dan (B) Lateral lidah dextra post hemiglossectomy

ukuran $\pm 3 \times 2 \mathrm{~cm}$, warna putih kekuningan, batas jelas, tepi ireguler, terdapat indurasi, daerah sekitar normal (Gambar 1A) dan dorsal lidah terdapat pseudomembran, berwarna putih, batas difus, tepi ireguler, daerah sekitar normal, dapat dikerok (Gambar 1B).

Berat badan pasien $59 \mathrm{~kg}$ dengan tinggi badan $160 \mathrm{~cm}$ dan $\mathrm{BMI}=23,04$ (normal). Diagnosa sementara pada kasus ini dari pemeriksaan subyektif dan obyektif adalah oral squamous cell carcinoma (OSCC) dengan diagnosa banding chronic traumatic ulcer dan oral tuberculosis ulcer.

Tindakan medis yang diberikan adalah debridement pada daerah lesi dan dorsal lidah menggunakan $\mathrm{NaCl}$ $0,9 \%$ dan kasa steril. Selanjutnya pasien diminta berkumur dengan antiseptik mouthwash dan obat kumur anastetikumantiinflamasi. Pasien selanjutnya diresepkan obat kumur povidone iodine untuk digunakan berkumur 4 kali sehari yaitu 3 kali setelah makan dan malam sebelum tidur sebanyak $10 \mathrm{ml}$ setiap berkumur dan benzydamine $\mathrm{HCl}$ oral rinse yang digunakan 3 kali sehari sebelum makan.

Pasien kemudian diberikan KIE meliputi kemungkinan penyakitnya dan kemungkinan penyebabnya, edukasi penggunaan obat kumur, instruksi untuk minum obat antinyeri maksimal 3 kali sehari, instruksi diet lunak dan menjaga kebersihan rongga mulutnya. Pasien dirujuk ke Laboratorium Patologi Klinik untuk dilakukan pemeriksaan darah lengkap, gula darah puasa dan $\mathrm{HbAlc}$ dan ke Departemen Patologi Anatomi untuk dilakukan scrapping dan FNAB pada lidah lateral dextra. Pasien juga direncanakan dilakukan grinding pada gigi 46 dan pasien diinstruksikan untuk kontrol.

Pasien datang kontrol 4 hari setelah kunjungan pertama yaitu pada tanggal 8 November 2019. Sariawan pada lidah kanan masih terasa nyeri. Pasien merasa ukuran sariawannya tidak mengalami perubahan. Pasien telah membeli obat yang diresepkan dan telah digunakan sesuai petunjuk, namun pasien mengeluhkan bahwa obat kumur yang diresepkan dirasa tidak nyaman oleh pasien. Terakhir pasien menggunakan obat kumur tadi pagi, povidone iodine masih sisa sedangkan benzydamine $\mathrm{HCl}$ sudah habis. Obat antinyeri pasien tersisa sekitar 15 biji. Pasien sudah menghindari makan makanan pedas dan berbumbu tajam. Pasien sudah diet lunak dan minum susu serta jus buah dan sayur. Pasien sudah melakukan pemeriksaan darah lengkap, gula darah puasa, HbAlc ke Lab Patologi Klinik dan Departemen Patologi Anatomi untuk scrapping dan FNAB tanggal 5 November 2019 (3 hari yang lalu).

Pemeriksaan ekstra oral tidak ada abnormalitas. Pemeriksaan klinis intra oral terdapat ulser, soliter, oval, ukuran \pm $3 \times 2 \mathrm{~cm}$, warna putih kekuningan, batas jelas, tepi ireguler, terdapat indurasi, daerah sekitar normal pada lidah lateral dextra dan pseudomembran, berwarna putih, batas difus, tepi ireguler, daerah sekitar normal, dapat dikerok pada dorsal lidah (Gambar 2).

Hasil pemeriksaan darah lengkap didapatkan penurunan nilai eosinofil dan limfosit serta kenaikan nilai neutrofil, monosit dan laju endap darah (Tabel 1). Akan tetapi nilai gula darah puasa dan HbAlc pada pasien juga masih dalam batas normal (Tabel 1).

Hasil pemeriksaan mikroskopik scrapping dan FNAB dari Patologi Anatomi pada hapusan hiposeluler mendapatkan sebaran dan kelompok selsel epithel squamous matur, berbentuk poligonal, berinti bulat-oval, sitoplasma luas. Latar belakang debris matrik dan sebaran sel radang neutrofil dan limfosit. Tidak tampak displasia maupun tandatanda keganasan pada pemeriksaan histopatologi anatomi.

Hasil hemiglosektomi selanjutnya dikirim ke Patologi Anatomi untuk dilakukan pemeriksaan histopatologi anatomi dan menunjukkan potongan jaringan dilapisi epitel squamous (Gambar 3). Akan tetapi, pada stroma tampak 
Tabel 1. Hasil pemeriksaan darah lengkap, gula darah puasa dan HbA1c

\begin{tabular}{|c|c|c|c|c|}
\hline Parameter & Hasil & Satuan & Nilai Rujukan & Interpretasi \\
\hline Hemoglobin & 12.5 & $\mathrm{~g} / \mathrm{dL}$ & $11.7-15.3$ & Normal \\
\hline Jumlah leukosit & 7.1 & $10^{3} / \mu \mathrm{L}$ & $3.6-11.0$ & Normal \\
\hline Trombosit & 258 & $10^{3} / \mu \mathrm{L}$ & $150-440$ & Normal \\
\hline Eosinofil & 1 & $\%$ & $2-4$ & Rendah \\
\hline Basofil & 0 & $\%$ & $0-1$ & Normal \\
\hline Neutrofil & 72 & $\%$ & $55-65$ & Tinggi \\
\hline Limfosit & 19 & $\%$ & $25-35$ & Rendah \\
\hline Monosit & 8 & $\%$ & $3-6$ & Tinggi \\
\hline Laju Endap Darah (LED) & 55 & $\mathrm{~mm}$ & $1-30$ & Tinggi \\
\hline Eritrosit & 4.3 & $10^{6} / \mu \mathrm{L}$ & $3.8-5.2$ & Normal \\
\hline Retikulosit & 0.6 & $\%$ & $0.5-1.5$ & Normal \\
\hline Hematokrit & 39 & $\%$ & $35-47$ & Normal \\
\hline Jumlah eosinofil & 100 & $\mu \mathrm{L}$ & $80-360$ & Normal \\
\hline $\mathrm{MCV}$ & 91 & $\mathrm{fL}$ & $80-100$ & Normal \\
\hline $\mathrm{MCH}$ & 29 & pg & $26-34$ & Normal \\
\hline $\mathrm{MCHC}$ & 32 & $\mathrm{~g} / \mathrm{dL}$ & $32-36$ & Normal \\
\hline Gula Darah Puasa (GDP) & 70 & $\mathrm{mg} / \mathrm{dL}$ & $<126$ & Normal \\
\hline $\mathrm{HbA} 1 \mathrm{c}$ & 5.4 & $\%$ & $<6.5$ & Normal \\
\hline
\end{tabular}

MCV: Mean Corpuscular Volume; MCH: Mean Corpuscular Hemoglobin; MCHC: Mean Corpuscular Hemoglobin Concentration; HbA1c: Hemoglobin Alc

pertumbuhan neoplasma yang terdiri dari proliferasi sel epitel squamous anaplasi dengan inti bulat, pleomorfik, kromatin kasar, anak inti prominen, sitoplasma eosinofilik tersusun dalam pola lembaran dan sarang-sarang dengan keratin pearl diantaranya (Gambar 3).

Diagnosa sementara adalah OSCC dan diagnosa banding chronic traumatic ulcer. Tatalaksana yang diberikan di RSGM adalah debridement daerah lesi dan dorsal lidah dengan saline $0,9 \%$. Pasien selanjutnya diresepkan chlorhexidine digluconate mouthwash $0,12 \%$ dan dirujuk ke Departemen Bedah Onkologi Kepala Leher untuk tatalaksana lebih lanjut.

Sebelas hari kemudian, tanggal 19 November 2019 pasien pergi ke Departemen Bedah Onkologi KL, diagnosa sementara yang diberikan adalah malignat neoplasma of tongue dan dianjurkan untuk dilakukan hemiglosektomi. Pasien mendapatkan jadwal operasi hemiglosektomi tanggal 18 Desember 2019 di RSI Jemursari. Pasien dirawat inap selama beberapa hari setelah operasi dan diberikan obat antibiotik serta antinyeri yang telah secara rutin dikonsumsi oleh pasien. Pasien tidak dapat datang untuk kontrol secara langsung ke RSGM sehingga kami menghubungi pasien melalui telemedicine pada tanggal 1 Februari 2020. Pemeriksaan subyektif didapatkan 2 bulan setelah operasi, tidak ada keluhan pada lidah pasien. Tidak ada keluhan nyeri saat makan dan menelan. Pemeriksaan intraoral pada lidah lateral dextra tidak ada abnormalitas (Gambar 4 dan 5).

\section{PEMBAHASAN}

Squamous Cell Carcinoma (SCC) merupakan keganasan pada jaringan epitel dengan prevalensi terbanyak. ${ }^{4}$ Oral Squamous Cell Carcinoma (OSCC) merupakan keganasan dengan prevalensi terbanyak pada rongga mulut, mencapai 90-95 \% kasus. Lokasi utama yang banyak ditemukan OSCC adalah pada lidah. ${ }^{5}$ Prevalensi dan epidemiologi OSCC dapat berbeda-beda pada setiap populasi di dunia. Perbedaan ini kemungkinan ada hubungannya dengan berbagai faktor diantaranya lingkungan, kebiasaan berisiko tinggi pada etnis tertentu dan adanya faktor genetik. ${ }^{6}$ Penggunaan tembakau, konsumsi alkohol berlebihan, konsumsi sayur dan buah yang lebih sedikit, genetika, trauma dan virus dianggap sebagai faktor risiko dari OSCC. ${ }^{2}$

Pada kasus ini, pasien merupakan seorang wanita berusia 45 tahun yang tidak menggunakan tembakau, tidak konsumsi alkohol namun terdapat saudara perempuan pasien memiliki riwayat kanker payudara dan dari pemeriksaan klinis intraoral ditemukan gigi cusp gigi 46 yang tajam. Berdasarkan hal tersebut kemungkinan faktor risiko yang dimiliki oleh pasien adalah adanya riwayat genetik dan trauma kronis akibat cusp gigi 46 yang tajam. Keluhan nyeri yang dirasakan pasien dikarenakan adanya infeksi sekunder dan keterlibatan saraf perifer. ${ }^{7}$

OSCC merupakan proses karsinogenesis multi tahapan yang terjadi karena adanya mutasi genetik di dalam sel. Mutasi genetik ini secara progresif menyebabkan kondisi hiperplastik yang diikuti oleh gambaran displasia sel, pertumbuhan sel yang tidak teratur, dan akhirnya terjadi karsinoma, Kerusakan materi genetik mengacu pada perubahan gen spesifik. Gen spesifik ini meliputi tumor suppressor genes dan protooncogenes, dimana gen-gen ini menyandi protein yang bertanggung jawab untuk mengontrol sel, transduksi sinyal dan mengatur transkripsi. ${ }^{1}$

Banyak penelitian telah dilakukan untuk mengevaluasi peran trauma kronis pada karsinogenesis. Suatu penelitian eksperimental menunjukkan bahwa trauma kronis dapat menyebabkan terjadinya kanker melalui iritasis mekanis yang persisten sehingga mengakibatkan kerusakan DNA. Ini telah dibuktikan dengan meningkatnya aktivitas poly- 
ADP-ribose polymerase dalam kasus trauma kronis. Mekanisme lainnya adalah trauma mukosa kronis menyebabkan terjadinya inflamasi, sehingga terjadi pelepasan mediator kimia seperti sitokin, prostaglandin dan tumor necrosis factor. ${ }^{8}$ Terjadinya inflamasi mengakibatkan adanya stress oksidatif, kondisi dapat menginduksi perubahan genetik dan epigenetic yang merusak DNA, menghambat perbaikannya, mengubah faktor transkripsi, mencegah apoptosis dan menstimulasi angiogenesis sehingga menyebabkan karsinogenesis. ${ }^{8}$

Pasien kami resepkan obat kumur povidone iodine mouthwash $1 \%$ karena memiliki efek antimikroba spektrum luas untuk mencegah infeksi sekunder dan bahan aktif iodine merupakan scavenger dari reactive oxygen species sehingga keberadaannya juga dapat bertindak sebagai antiinflamasi dan benzydamine $\mathrm{HCl}$ mouthwash yang merupakan anti inflamasi non steroid topikal, memiliki efek anti inflamasi, analgesik dan anastesi lokal.9-11 Namun karena pada kunjungan kedua pasien merasa tidak nyaman menggunakan obat kumur tersebut, kami menggantinya dengan chlorhexidine digluconate $0,12 \%$ yang merupakan antiseptik topikal yang juga efektif terhadap berbagai mikroba seperti bakteri gram positif, gram negatif, jamur dan virus. ${ }^{12}$

Pasien dirujuk pemeriksaan darah lengkap untuk menilai status kesehatan pasien secara umum dan dilakukan pemeriksaan gula darah puasa serta HbA1c karena keluarga pasien memiliki riwayat penyakit diabetes mellitus. Nilai eosinofil turun, kemungkinan karena pengambilan darah dilakukan di pagi hari dimana jumlah eosinofil rendah pada pagi hari. Limfosit menurun menandakan adanya infeksi dan trauma. Peningkatan nilai neutrofil, monosit, dan laju endap darah diketahui terkait dengan adanya infeksi akut atau kronis. ${ }^{13}$

Untuk mendukung penegakan diagnosis, pasien dirujuk ke Departemen Patologi Anatomi dan dilakukan pemeriksaan sitologi eksfoliatif dengan scrapping dan FNAB. Sitologi eksfoliatif adalah suatu pemeriksaan sel secara mikroskopis yang diperoleh dari permukaan lesi setelah dilakukan pewarnaan yang sesuai. Untuk mendapatkan sel-sel neoplastik dilakukan dengan scrapping atau menggosok permukaan lesi kemudian mengevaluasi perubahan sel yang terjadi seperti displasia atau keganasan. ${ }^{7}$ Hasil pemeriksaan sitologi eksfoliatif menunjukkan tidak tampak displasia dan tanda-tanda keganasan. Pasien kemudian kami rujuk ke Departemen Bedah Onkologi Kepala Leher untuk dilakukan tatalaksana lebih lanjut.

Staging TNM yang dikembangkan oleh The American Joint Committee on Cancer (AJCC) berpengaruh terhadap prognosis dan strategi perawatan. $\mathrm{T}$ merupakan ukuran tumor primer, $\mathrm{N}$ mengindikasikan adanya nodus limfe regional, dan $\mathrm{M}$ mengindikasikan metastasis. ${ }^{1,4}$ Pada pasien ini, berdasarkan AJCC, klasifikasi stadiumnya T2N0M0 artinya ukuran tumor primer antara 2 hingga $4 \mathrm{~cm}$, tidak teraba pembesaran kelenjar getah bening regional dan tidak ada metastasis jauh. Berdasarkan penggolongan stadium klinis, kasus ini termasuk ke stadium II sehingga dilakukan pembedahan yang merupakan pilihan utama untuk pasien stadium I dan II. ${ }^{1,14}$

Tatalaksana pasien dilakukan tindakan hemiglosektomi. Hemiglosektomi adalah suatu tindakan pembedahan dengan cara pengangkatan tumor secara keseluruhan dan utuh dengan batas yang adekuat (1-2 $\mathrm{cm}$ dari tepi jaringan sehat). Indikasi dari tindakan ini adalah kasus kanker lidah yang operabel, keadaan umum pasien baik dan tidak ada komorbid berat. Hasil operasi dikirim untuk dilakukan pemeriksaan patologi anatomi dan menunjukkan adanya gambaran proliferasi sel-sel skuamosa disertai keratin pearl, sehingga diagnosa akhirnya adalah OSCC well differentiated. ${ }^{14}$

\section{SIMPULAN}

Dokter gigi memiliki peran yang penting dalam mengidentifikasi OSCC. Diagnosa dini dan manajemen multidisiplin OSCC yang tepat dapat meningkatkan prognosa kasus dan kualitas hidup pasien.

\section{KONFLIK KEPENTINGAN}

Penulis menyatakan tidak terdapat konflik kepentingan terkait publikasi dari laporan kasus ini.

\section{PENDANAAN}

Laporan kasus ini tidak mendapatkan pendanaan dari pemerintah ataupun lembaga sektor swasta lainnya.

\section{ETIKA PENELITIAN}

Pasien telah menandatangani lembar inform consent dan setuju bahwa foto klinis dari pasien akan dipublikasikan di jurnal ilmiah kedokteran berdasarkan pedoman COPE dan ICMJE.

\section{KONTRIBUSI PENULIS}

Semua penulis berkontribusi terhadap laporan kasus ini baik dari perencanaan, pencarian data pasien, analisis data pasien, dan penyusunan naskah laporan kasus.

\section{DAFTAR PUSTAKA}

1. Gharat SA, Momin M, Bhavsar C. Oral Squamous Cell Carcinoma: Current Treatment Strategies and Nanotechnology-Based Approaches for Prevention and Therapy. Crit Rev Ther Drug Carrier Syst. 2016;33(4):363400.

2. Mahawar P, Reddy S, Bhasin M, Kakkad A, Yadav A. Oral Squamous Cell Carcinoma Case Series: A Saga of Reactions Against Risk Factors. Journal of Dental and Medical Sciences. 2020;19(7):55-60.

3. Feller L, Lemmer J. Oral Squamous Cell Carcinoma: Epidemiology, Clinical Presentation and Treatment. Journal of Cancer Therapy. 2012;3(4):263-268.

4. Parvathaneni U, Lavertu P, Gibson MK, Glastonbury CM. Advances in Diagnosis and Multidisciplinary Management of Oropharyngeal Squamous Cell Carcinoma: State of the Art. Radiographics. 2019;39(7):20552068.

5. França DC, Monti LM, de Castro AL, Soubhia AM, Volpato LE, de Aguiar SM, Goiato MC. Unusual presentation of oral squamous cell carcinoma in a young woman. Sultan Qaboos Univ Med J. 2012;12(2):228-31

6. Khammissa RA, Meer S, Lemmer J, Feller L. Oral squamous cell carcinoma in a South African sample: Race/ethnicity, age, gender, and degree of histopathological differentiation. J Cancer Res Ther. 2014;10(4):908-914.

7. Connelly ST, Schmidt BL. Evaluation of pain in patients with oral squamous cell carcinoma. J Pain. 2004;5(9):505-510.

8. Singhvi HR, Malik A, Chaturvedi P. The Role of Chronic Mucosal Trauma in Oral Cancer: A Review of Literature. Indian J Med Paediatr Oncol. 2017;38(1):44-50.

9. Kanagalingam J, Feliciano R, Hah JH, Labib H, Le TA, Lin JC. Practical use of povidone-iodine antiseptic in the maintenance of oral health and 
in the prevention and treatment of common oropharyngeal infections. Int J Clin Pract. 2015;69(11):1247-1256.

10. Abdel Moneim AE, Guerra-Librero A, Florido J, Shen YQ, Fernández-Gil B, AcuñaCastroviejo D, et al. Oral Mucositis: Melatonin Gel an Effective New Treatment. Int J Mol Sci. 2017;18(5):1003.

11. Jakubowski P, Lukasz P, Waldemar G. Recreational Use of Popular OTC DrugsPharmacological Review. Farmacia. 2018;66(2):209-2015.
12. Vijayalakshmi S, Rajasekar S, Mohankumar A. Antagonistic Activity of Multi-functional Gold Standard Chlorhexidine Against Lactobacillus acidophilus Isolated from Childhood Caries. International Journal of Biology Research. 2018;3(1):295-299.

13. Siddeshappa ST, Nagdeve S, Yeltiwar RK, Parvez H, Deonani S, Diwan V. Evaluation of various hematological parameters in patients with periodontitis after nonsurgical therapy at different intervals. J Indian Soc Periodontol. 2016;20(2):180-183.
14. Spencer KR, Ferguson JW, Wiesenfeld D. Current concepts in the management of oral squamous cell carcinoma. Aust Dent J. 2002;47(4):284-351.

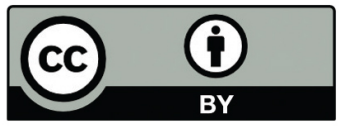

This work is licensed under a Creative Commons Attribution 